\title{
LUMINESCENT AIN:Mn NANOPARTICLES FOR OPTICAL IMAGING OF BIOLOGICAL MATERIALS
}

\author{
B. Berzina, L. Trinkler, V. Korsaks, R. Ruska \\ Institute of Solid State Physics, University of Latvia, 8 Kengaraga Str., Riga, LV-1063, Latvia \\ e-mail:baiber@latnet.lv \\ Submitted November 12, 2019 \\ Accepted January 30, 2020
}

\begin{abstract}
Background: Elaboration of new luminescent nanomaterials for imaging of biological materials including cells of living organisms and their parts is highly actual. These materials must meet a number of requirements such as low toxicity, inherence of intensive luminescence, low costs of raw material and symple synthesis methods. AlN nanopowder is one of such prospective materials fitting the above requirements. Our long time investigations on spectral characteristics for III group element nitrides allows chose of doped AIN nanopowder as prospective candidate for developing of luminescent markers for imaging of biological materials.
\end{abstract}

Objectives: The aim of the present study is spectral characterization of AlN nanopowder doped with Mn and evaluation of its use as luminescent marker for biological materials.

Materials and methods: AlN nanopowder with average size of polycrystalline grains of $60 \mathrm{~nm}$ and the same doped with Mn were sythesized in Institue of Inorganic Chemistry, Riga Technical University. Photoluminescence and its excitation spectra of the materials were studied at room temperature using a self-made set-up.

Results: It was found that in undoped AIN nanopowder at room temperature luminescence of native defects forms a wide and complex band peaking at $415 \mathrm{~nm}$. This blue luminescence can be excited with ultraviolet light from two spectral regions around 315-340 nm and $260 \mathrm{~nm}$. Two luminescence mechanisms are proposed dependent on the spectral region of exciting light. The first of them results in the intra-center luminescence, but the second one is recombination luminescence.

Incorporation of $\mathrm{Mn}$ atoms in the crystalline lattice of AIN nanopowder forming AlN:Mn NP results in appearance of intensive red luminescence at $600 \mathrm{~nm}$, which can be excited with light from two excitation bands at 260 and $480 \mathrm{~nm}$. Two mechanisms responsible for an appearence of the red luminescence of Mn are proposed. They are the intra-center luminescence and recombination luminescence mechanisms. In this case the red Mn luminiscence prevails and the blue luminescence characterizing the host material has not been observed.

Conclusions: AlN nanopowder doped with $\mathrm{Mn}$ atoms is a prospective material for use as luminescent marker for imaging of biological materials. Properties of this material are in a good agreement with the main requirements obligated to biological materials: i) AlN NP has low toxicity; ii) AlN:Mn NP possesses intensive red luminescence at $600 \mathrm{~nm}$, which can be excited either with the ultraviolet light around $260 \mathrm{~nm}$ or with visible light around $480 \mathrm{~nm}$; iii) it is relatively cheep material and it can be synthesized using simple synthesis methods.

KEY WORDS: aluminum nitride; nanopowder; aluminum nitride doped with Mn; photoluminescence; excitation spectra; biological materials.

\section{ЛЮМІНІСЦЕНТНІ AIN:Mn НАНОЧАСТИНКИ ДЛЯ ОПТИЧНОГО ЗОБРАЖЕННЯ БІОЛОГІЧНИХ МАТЕРІАЛІВ \\ Б. Берзіна, Л. Трінклер, В. Корсакс, Р. Руска}

Інститут твердого тіла, Університет Латвії, вул. Кенгарага, 8, Рига, LV-1063, Латвія

Актуальність. Розробка нових люмінесцентних наноматеріалів для візуалізації біологічних матеріалів, включаючи клітини та їх складові, є досить актуальною. Ці матеріали повинні відповідати ряду вимог, таких як низька токсичність, висока інтенсивність люмінесценції, низькі витрати сировини та прості методи синтезу. Нанопорошок AlN - один з таких перспективних матеріалів, що відповідають вищезазначеним вимогам. Наші багаторічні дослідження 
спектральних характеристик нітридів елементів III групи дозволяють обрати легований нанопорошок AIN для розробки люмінесцентного маркера для візуалізації біологічних матеріалів. Мета роботи. Мета цього дослідження - спектральна характеристика нанопорошку $\mathrm{AlN}$, легованого $\mathrm{Mn}$, та оцінка можливості його використання як люмінесцентного маркера для біологічних матеріалів.

Матеріали і методи. Нанопорошок $\mathrm{AIN}$ із середнім розміром полікристалічних зерен 60 нм та Mn такого ж розміру зерен, був синтезований в Інституті неорганічної хімії Ризького технічного університету. Фотолюмінесценцію та спектри збудження матеріалів вивчали при кімнатній температурі за допомогою установки, виготовленої в нашому інституті.

Результати. Було встановлено, що в нелегованому нанопорошку AlN при кімнатній температурі люмінесценція нативних дефектів утворює широку і складну смугу на довжині хвилі 415 нм. Ця синя люмінесценція може збуджуватися ультрафіолетовим світлом 3 двох спектральних областей приблизно 315-340 нм і 260 нм. Запропоновано два механізми люмінесценції залежно від спектральної області збуджуючого світла. Першим з них є внутрішньоцентрова люмінесценція, а другим — рекомбінаційна люмінесценція.

Включення атомів Mn у кристалічну решітку нанопорошку AlN, що утворює AlN:Mn наночастинки, призводить до появи інтенсивної червоної люмінесценції при 600 нм, яка може збуджуватися світлом з двох смуг збудження на 260 та 480 нм. Запропоновано два механізми, що відповідають за появу червоної люмінесценції $\mathrm{Mn}$ : внутрішньоцентрова та рекомбінаційна люмінесценція. У цьому випадку переважає червона емісія $\mathrm{Mn}$ і не спостерігається синя люмінесценція, що характеризує матеріал нелегований AlN.

Висновки. Нанопорошок $\mathrm{AlN}$, легований атомами $\mathrm{Mn}$, $\epsilon$ перспективним матеріалом для використання як люмінесцентного маркера для зображення біологічних матеріалів. Властивості цього матеріалу добре узгоджуються 3 основними вимогами до біологічних маркерів: i) AlN наночастинки мають низьку токсичність; ii) AlN:Mn наночастинки мають інтенсивну червону люмінесценцію при 600 нм, яку можна збуджувати або ультрафіолетовим світлом близько 260 нм, або видимим світлом близько 480 нм; iii) це відносно дешевий матеріал, і його можна отримати за допомогою простих методів синтезу.

КЛЮЧОВІ СЛОВА: нітрид алюмінію; нанопорошок; нітрид алюмінію, легований Мn; фотолюмінесценція; спектри збудження; біологічні матеріали.

\section{ЛЮМИНИСЦЕНТНЫЕ AIN:Mn НАНОЧАСТИЦЫ ДЛЯ ОПТИЧЕСКОГО ИЗОБРАЖЕНИЯ БИОЛОГИЧЕСКИХ МАТЕРИАЛОВ}

Б. Берзина, Л. Тринклер, В. Корсакс, Р. Руска

Институт твердого тела, Университет Латвии, ул. Кенгарага, 8, Рига, LV-1063, Латвия

Актуальность. Разработка новых люминесцентных наноматериалов для визуализации биологических материалов, включая клетки и их составляющие, является довольно актуальной. Эти материалы должны отвечать ряду требований, таких как низкая токсичность, высокая интенсивность люминесценции, низкие расходы сырья и простые методы синтеза. Нанопорошок AIN - один из таких перспективных материалов, которые отвечают вышеупомянутым требованиям. Наши многолетние исследования спектральных характеристик нитридов элементов III группы позволяют избрать легированный нанопорошок AIN для разработки люминесцентного маркера для визуализации биологических материалов.

Цель работы. Цель этого исследования - спектральная характеристика нанопорошка $\mathrm{AlN}$, легированного $\mathrm{Mn}$, и оценка возможности его использования как люминесцентного маркера для биологических материалов.

Материалы и методы. Нанопорошок AIN со средним размером поликристаллических зерен 60 нм и Mn с таким же размером зерен, был синтезирован в Институте неорганической химии Рижского технического университета. Фотолюминесценцию и спектры возбуждения материалов изучали при комнатной температуре с помощью установки, изготовленной в нашем институте.

Результаты. Было установлено, что в нелегированном нанопорошке AIN при комнатной температуре люминесценция нативных дефектов образует широкую и сложную полосу на длине волны 415 нм. Эта синяя люминесценция может возбуждаться ультрафиолетовым светом из двух спектральных областей приблизительно 315-340 нм и 260 нм. Предлагается два механизма люминесценции в зависимости от спектральной области возбуждающего света. Первым из них является внутреннецентровая люминесценция, а вторым - рекомбинационная люминесценция.

Включение атомов Mn в кристаллическую решетку нанопорошка AlN, что образовывает AlN:Mn наночастицы, приводит к появлению интенсивной красной люминесценции при 600 нм, которая 
может возбуждаться светом с двух полос возбуждения на 260 и 480 нм. Предлагается два механизма, которые отвечают за появление красной люминесценции Mn: внутреннецентровая и рекомбинационная люминесценция. В этом случае преобладает красная эмиссия Мn и не наблюдается синяя люминесценция, которая характеризует материал нелегированный AlN.

Выводы. Нанопорошок AlN, легированный атомами Mn, является перспективным материалом для использования в качестве люминесцентного маркера для изображения биологических материалов. Свойства этого материала хорошо согласуются с основными требованиями к биологическим маркерам: i) AlN наночастицы имеют низкую токсичность; ii) AlN:Mn наночастицы имеют интенсивную красную люминесценцию при 600 нм, которую можно возбуждать или ультрафиолетовым светом вблизи 260 нм, или видимым светом вблизи 480 нм; iii) это относительно дешевый материал, и его можно получить с помощью простых методов синтеза.

КЛЮЧЕВЫЕ СЛОВА: нитрид алюминия; нанопорошок; нитрид алюминия, легированный $\mathrm{Mn}$; фотолюминесценция; спектры возбуждения; биологические материалы.

At present elaboration of new luminescent nanomaterials is in progress due to their suitability in different fields of application including smart technologies and life sciences. One direction of this application can be related to biology and medicine. Due to a small size of nanomaterials being much smaller than the dimensions of the cells of living beings, it is possible to use the luminescent nanomaterials as luminescent markers for biological materials or controllable agents for drug transport in medicine. In order to use a particular material as a luminescent marker its properties must satisfy a number of requirements: $i$ ) low toxicity of the material, ii) intensive and controllable luminescence of the material in a convenient spectral region, iii) low costs of raw material and simple synthesis methods. Our long-time investigations on spectral properties of III group element nitrides allow prediction that doped AlN nanopowder in general could satisfy these requirements.

Aluminum nitride (AIN) is luminescent wide band gap solid state material with wurtzite crystalline structure possessing a lot of excellent properties such as high thermal stability and hardness, high thermal conductivity and low electrical conductivity [1,2]. Different forms of AlN material are known including bulk materials such as the single crystals and ceramics, and nanosize ones (nano particles, nanorods, nanotubes etc.). AlN is characterized with a wide band gap exceeding $6 \mathrm{eV}$ [3-5]. Different types of defects are characteristic for this material including point defects, which are mainly responsible for the luminescent properties of the material [6-9]. The main point defects in AIN crystalline lattice can be related to the host material caused by $\mathrm{Al}$ or $\mathrm{N}$ vacancies $\left(\mathrm{v}_{\mathrm{Al}}, \mathrm{v}_{\mathrm{N}}\right.$, respectively), interstitials $\left(i_{\mathrm{Al}}, i_{\mathrm{N}}\right)$ and others. Besides, the point defects can be caused by the dopants such as oxygen and carbon atoms substituting for the host nitrogen which are forming the so-called native defects incorporated during the synthesis of the material or specially added dopants. All these defects are forming their energy levels inside the band gap in thus determining optical properties of the material.

The aim of this study is spectral characterization of AlN nanopowder doped with $\mathrm{Mn}$ together with evaluation of its use as luminescent marker for biological materials.

\section{MATERIALS AND METHODS}

AlN nanopowder (NP) consisting of polycrystalline grains with average size of $60 \mathrm{~nm}$ was synthesized in Institute of Inorganic Chemistry, Riga Technical University by using plasma-chemical synthesis [10]. Raw aluminum powder $(99.4 \%)$ with particle size in the range of $20-40 \mu \mathrm{m}$ was injected and evaporated into nitrogen (99.9\%) high-frequency plasma flow. In order to promote formation of AIN and to reduce particle growth ammonia was introduced additionally in high temperature flow containing aluminum vapors.

AlN NP doped with Mn - AlN:Mn NP was prepared in similar way by injection of mechanical mixture of aluminum with manganese (Fluka, 99\%) into plasma flow.

Photoluminescence (PL) and excitation (PLE) spectra of AlN NP and doped AlN:Mn NP were measured at room temperature (RT) using a home-made set-up, consisting of the 
following parts: $i$ ) a sample holder mounted inside of the sample chamber of a closed cycle refrigerator (CCS-100/204, Janis Research Corporation); ii) a light source - a deuterium lamp (LD-400) for luminescence excitation and iii) a luminescence recording system containing the grating monochromator (Andor Schamrock SR-303i-B) together with the photomultiplier (Hamamatsu H7468-03). All necessary spectral corrections related to the measurements are taken into account.

\section{RESULTS AND DISCUSSION}

Spectral characteristics of the raw material - AlN NP and doped AlN:Mn NP have been studied at room temperature.

AIN NP. Photoluminescence and its excitation spectra of AIN NP are shown on Fig. 1, a, and $b$, respectively. As it is seen from the Fig. 1, a, irradiation of the AlN NP sample with light from the ultraviolet (UV) spectral region results in appearance of a wide and complex blue luminescence band peaking at $415 \mathrm{~nm}$ (the blue luminescence - BL). This BL can be excited within a wide spectral region of UV light consisting of several sub-bands (Fig. 1, b). This spectral region covering the defect-induced absorption in AlN NP can be divided into I and II spectral intervals.
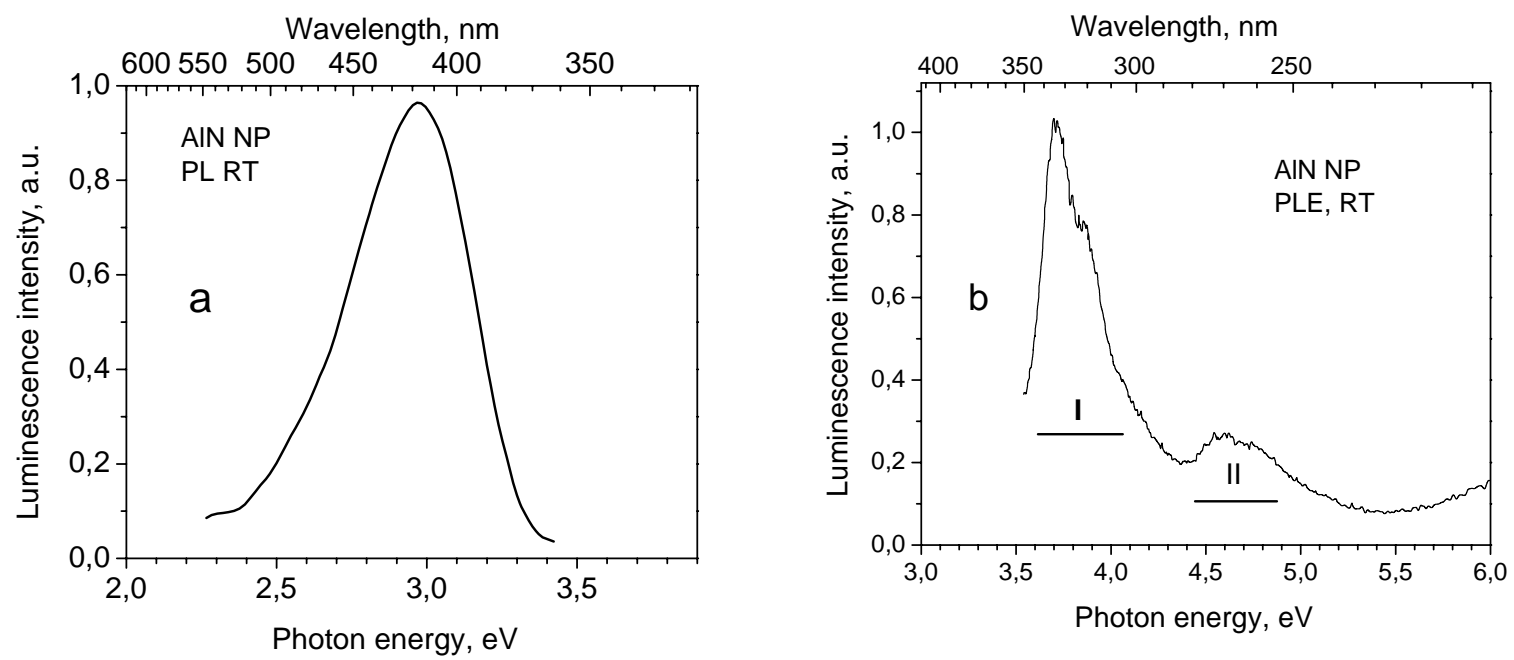

Fig. 1. AlN NP, RT. a - photoluminescence spectrum at $335 \mathrm{~nm}$ excitation at room temperature. $\mathrm{b}$ - luminescence excitation spectrum.

Analysis of the spectra depicted on Fig. 1, a, and b allows revealing of two mechanisms causing the native defect-induced BL. One of them is intra-center mechanism, when light absorption and emission occur inside one and the same defect. This mechanism is realized when the exciting UV light corresponds to the spectral interval I depicted on Fig. 1, b. This assumption is based on the following facts. Firstly, the maxima of the luminescence and excitation bands are situated very close and difference between them (the so-called Stokes shift) does not exceed $1 \mathrm{eV}$ (Fig. 1, a, and b), which is characteristic for the intra-center processes. Secondly, our recent measurements of luminescence kinetics showed that in this case the BL decay forms an exponential pulse with the decay time of an order of $10^{-7} \mathrm{~s}$, characterizing the intra-center luminescence [11].

When the exciting light is corresponding to the II spectral interval (Fig. 1, b) the BL formation most credibly is caused by the recombination processes. In this case there are two different but mutually interacting defect types, when one of them is responsible for absorption of the exciting light, but the other one - for light emission. There are several observations 
speaking in favor of this assumption. i) As it is seen from the (Fig. 1), in this case the Stokes shift energy is about $2 \mathrm{eV}$, considerably exceeding the value typical for the intra-center luminescence processes. ii) Besides, it is known that irradiation of bulk AlN (ceramics) with light from the spectral interval of $250-270 \mathrm{~nm}$ results in appearance of recombination processes causing the luminescence of oxygen-related defects [12-17] together with an energy storage in material, which can be released via thermally or optically stimulated processes [1821].

For identification of the defect types responsible for the BL in AlN NP, at first we can exclude the well-known oxygen-related defects observed in bulk AIN, which also emit the blue luminescence [16], because the total PLE spectrum of this luminescence differs from that observed in the present investigation. We assign the native defects, which are responsible for the BL luminescence in AIN NP to nitrogen vacancy type defects known as the so-called Fcenters [22]. This assumption is in a good agreement with the results obtained from the theoretical studies of AlN where presence of deep energy levels within the band gap of AlN caused by nitrogen vacancy type defects are revealed [23-25].

The BL mechanisms and involved defects are more detailed discussed in our recent paper [31].

AIN:Mn NP. PL and PLE spectra of AlN:Mn NP measured at RT are depicted on Fig. 2, $a$ and $b$, respectively. The PL spectrum consists of a single band peaking at $600 \mathrm{~nm}$, having an asymmetric long wavelength side extending up to $800 \mathrm{~nm}$, which could include several subbands with low intensity. The spectral position of $600 \mathrm{~nm}$ for Mn luminescence is in a good agreement with those observed by other authors [26, 27]. The PLE spectrum of Mn luminescence consists of two main bands (Fig. 2, b). One of them at $480 \mathrm{~nm}$ with a shoulder at $400 \mathrm{~nm}$ can be related to the direct absorption of Mn defects, whereas the PLE band at 260 $\mathrm{nm}$ seems to be coincident with excitation of the recombination BL band in AIN NP (Fig. 1, b). It allows assumption that irradiation of AlN:Mn NP with $260 \mathrm{~nm}$ light results in $600 \mathrm{~nm}$ Mn luminescence caused by recombination processes.
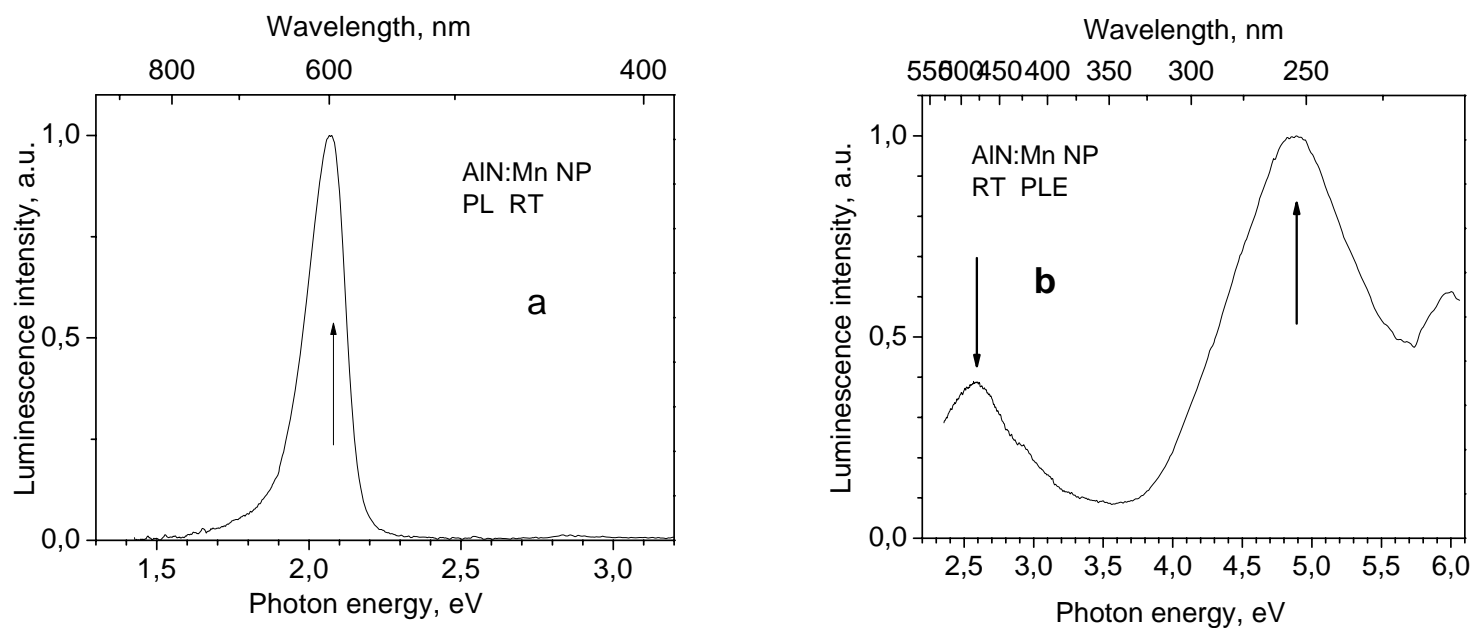

Fig. 2. AlN:Mn NP, RT. a - photoluminescence spectrum under $260 \mathrm{~nm}$ excitation. b - luminescence excitation spectrum.

In summary, the results observed allow conclusion that in AlN:Mn NP Mn impurity is forming a luminescence center, which can be excited either directly by $480 \mathrm{~nm}$ light absorption accordingly to the intra-center luminescence mechanism, or through absorption of $260 \mathrm{~nm}$ light resulting in recombination luminescence mechanism. Besides, for AlN:Mn NP the BL at $415 \mathrm{~nm}$ which is characteristic for AlN NP (Fig. 1, a) is not observable. It allows 
assumption, that for doped AIN NP the impurity luminescence is usually more intensive than that caused by the nitrogen vacancy type native defects.

Spectral properties of AIN:Mn NP emitting intensive red luminescence are clearing the way of material for application as luminescent markers of biological objects. Besides, it is reasonably to consider, that AIN NP is with low toxicity, because it is never mentioned in the lists of toxic nanomaterials observable in the annual reports of leading supervising companies [28-30]. Nevertheless, it seems reasonable to test the toxicity of AIN NP in future.

In summary, we can conclude that properties of AIN nanopowder doped with Mn atoms are in a good agreement with the main requirements for biological sensors: $i$ ) it does not belong to the materials with high toxicity; ii) AlN:Mn NP possesses intensive red luminescence at $600 \mathrm{~nm}$, which can be excited either with the ultraviolet light around $260 \mathrm{~nm}$ or with visible light around $480 \mathrm{~nm}$; iii) it is relatively cheep material and it can be synthesized using simple synthesis methods.

\section{CONCLUSIONS}

In summary, the present spectral investigations of AIN nanopowder and the same doped with $\mathrm{Mn}$ atoms allow the following conclusions. $i$ ) In AIN NP the native defect-caused blue luminescence around $415 \mathrm{~nm}$ appears, which can be excited either via intra-center processes with UV light from 315-340 $\mathrm{nm}$ spectral region or through recombination processes caused by the sample irradiation with light from $250-270 \mathrm{~nm}$ spectral region. The luminescent defects responsible for the BL can be related to the so-called F-centers based on nitrogen vacancies. ii) For AlN:Mn NP the Mn-caused intensive red luminescence at $600 \mathrm{~nm}$ is predominant, which can be excited either by UV light around $260 \mathrm{~nm}$ or visible light at 400 $480 \mathrm{~nm}$. iii) AlN:Mn NP is a prospective material for use as a luminescent marker for imaging of biological materials.

\section{ACKNOWLEDGMENT}

This work has been supported by the HORIZON 2020 project "Asymmetry of biological membrane: theoretical, experimental and applied aspects" (690853-assymcurv-H2020-MSCARISE-2015).

\section{CONFLICT OF INTEREST}

The authors report that there is no conflict of interest.

\section{AUTHORS' ORCID ID}

B. Berzina (Dhttps://orcid.org/0000-0003-0896-0199

L. Trinkler (iD https://orcid.org/0000-0003-0477-8736

\section{REFERENCES}

1. Palmer DW. Electronic Energy Levels in Group-III Nitrides. In: Bhattacharya P, Fornari R, Kamimura H, editors. Comprehensive Semiconductor Science and Technology. Vol. 4, Materials, Preparation, and Properties. Amsterdam: Elsevier; 2011. p. 390-447. https://doi.org/10.1016/b978-0-44-453153-7.00114-0

2. Rutz RF. Ultraviolet electroluminescence in AlN. Appl Phys Lett. 1976;28(7):379-81. https://doi.org/10.1063/1.88788

3. Feneberg M, Leute RAR, Neuschl B, Thonke K, Bickermann M. High-excitation and high-resolution photoluminescence spectra of bulk AlN. Phys Rev B. 2010 Aug 16;82(7):075208. https://doi.org/10.1103/PhysRevB.82.075208

4. Li J, Nam KB, Nakarmi ML, Lin JY, Jiang HX, Carrier P, et al. Band structure and fundamental optical transitions in wurtzite AIN. Appl Phys Lett. 2003 Dec 22;83(25):5163-5. https://doi.org/10.1063/1.1633965

5. Silveira E, Freitas JA, Schujman SB, Schowalter LJ. AlN bandgap temperature dependence from its optical properties. J Cryst Growth. 2008 Aug;310(17):4007-10. https://doi.org/10.1016/j.jcrysgro.2008.06.015 
6. Tansley TL, Egan RJ. Point-defect energies in the nitrides of aluminum, gallium, and indium. Phys Rev B. 1992 May 15;45(19):10942-50. https://doi.org/10.1103/PhysRevB.45.10942

7. Gorczyca I, Svane A, Christensen N. Calculated defect levels in GaN and AlN and their pressure coefficients. Solid State Communications. 1997 Mar;101(10):747-52. https://doi.org/10.1016/S0038-1098(96)00689-8

8. Mattila T, Nieminen RM. Point-defect complexes and broadband luminescence in GaN and AlN. Phys Rev B. 1997 Apr 15;55(15):9571-6. https://doi.org/10.1103/PhysRevB.55.9571

9. Koppe T, Hofsäss H, Vetter U. Overview of band-edge and defect related luminescence in aluminum nitride. Journal of Luminescence. 2016 Oct;178:267-81. https://doi.org/10.1016/j.jlumin.2016.05.055

10. Grabis J, Steins I, Patmalnieks A, Berzina B, Trinklere L. Preparation and processing of doped AlN nanopowders. Estonian J Eng. 2009;15(4):266. https://doi.org/10.3176/eng.2009.4.03

11. Stepanov BI, Gribkovskii VP. Theory of Luminescence. English edition. Chornet S, editor. London: Iliffe Books Ltd; 1968. 497 p. ISBN-10: 0592050467, ISBN-13: 978-0592050461

12. Slack G.A., Menelly T.F. Growth of high purity AIN crystals. J Cryst Growth. 1976;34:263-279. https://doi.org/10.1016/0022-0248(76)90139-1

13. Youngman RA, Harris JH. Luminescence Studies of Oxygen-Related Defects In Aluminum Nitride. Journal of the American Ceramic Society. 1990 Nov;73(11):3238-46. https://doi.org/10.1111/j.1151-2916.1990.tb06444.x

14. Berzina B, Trinkler L, Sils J, Palcevskis E. Oxygen-related defects and energy accumulation in aluminum nitride ceramics. Radiation Effects and Defects in Solids. 2001 Dec;156(1-4):241-7. https://doi.org/10.1080/10420150108216900

15. Berzina B, Trinkler L, Sils J, Atobe K. Luminescence mechanisms of oxygen-related defects in AlN. Radiation Effects and Defects in Solids. 2002 Jan;157(6-12):1089-92. https://doi.org/10.1080/10420150215822

16. Berzina B., Trinkler L., Jakimovica L, Korsaks V, Grabis J, Steins I, Palcevskis E, Belluci S, Chen LC, Chattopadhyay S, Chen K. Spectral characterization of bulk and nanostructured aluminum nitride. J Nanophoton. 2009 Dec 1;3(1):031950. https://doi.org/10.1117/1.3276803

17. Schweizer S, Rogulis U, Spaeth JM, Trinkler L, Berzina B. Investigation of Oxygen-Related Luminescence Centres in AlN Ceramics. physica status solidi (b). 2000 June 14;219(1):171-180. https://doi.org/10.1002/1521-3951(200005)219:1<171::AID-PSSB171>3.0.CO;2-0

18. Trinkler L, Bos A, Winkelman A, Christensen P, Angersnap Larsen N, Berzina B. Thermally and Optically Stimulated Luminescence of $\mathrm{AlN}-\mathrm{Y}_{2} \mathrm{O}_{3}$ Ceramics after Ionising Irradiation. Radiation Protection Dosimetry. 1999 Aug 1;84(1):207-10. https://doi.org/10.1093/oxfordjournals.rpd.a032718

19. Trinkler L, Bøtter-Jensen L, Christensen P, Berzina B. Stimulated luminescence of AlN ceramics induced by ultraviolet radiation. Radiation Measurements. 2001 Oct;33(5):731-5. https://doi.org/10.1016/S13504487(01)00093-2

20. Trinkler L, Bøtter-Jensen L, Berzina B. Aluminium Nitride Ceramics: A Potential UV Dosemeter Material. Radiation Protection Dosimetry. 2002 Jul 1;100(1):313-6. https://doi.org/10.1093/oxfordjournals.rpd.a005876

21. Trinkler L, Berzina B. Recombination luminescence in aluminum nitride ceramics. physica status solidi (b). 2014 Mar;251(3):542-8. https://doi.org/10.1002/pssb.201350090

22. Schulman JH, Compton WD. Color Centers in Solids. Oxford: Pergamon Press; 1962. p.368

23. Stampfl C, Van de Walle CG. Theoretical investigation of native defects, impurities, and complexes in aluminum nitride. Phys Rev B. 2002 Apr 15;65(15):155212. https://doi.org/10.1103/PhysRevB.65.155212

24. Soltamov V, Ilyin I, Soltamova A, Tolmachev D, Mokhov E, Baranov P. Identification of the deep-level defects in AIN single crystals: EPR and TL studies. Diamond and Related Materials. 2011 Jul;20(7):1085-9. https://doi.org/10.1016/j.diamond.2011.04.009

25. Lan Y, Chen X, Cao Y, Xu Y, Xun L, Xu T, et al. Low-temperature synthesis and photoluminescence of AlN. J Cryst Growth. 1999 Dec;207(3):247-50. https://doi.org/10.1016/S0022-0248(99)00448-0

26. Lei F, Lei X, Ye Z, Zhao N, Yang X, Shi Z, et al. Photoluminescent properties of AlN:Mn ${ }^{2+}$ phosphors. Journal of Alloys and Compounds. 2018 Sep;763:466-70. https://doi.org/10.1016/j.jallcom.2018.05.291

27. Xu J, Cherepy NJ, Ueda J, Tanabe S. Red persistent luminescence in rare earth-free AlN:Mn ${ }^{2+}$ phosphor. Materials Letters. 2017 Nov;206:175-7. https://doi.org/10.1016/j.matlet.2017.07.015

28. Jeevanandam J, Barhoum A, Chan YS, Dufresne A, Danquah MK. Review on nanoparticles and nanostructured materials: history, sources, toxicity and regulations. Beilstein J Nanotechnol. 2018 Apr 3;9:1050-74. https://doi.org/10.3762/bjnano.9.98

29. Zhou L, Zhuang W, Wang X, Yu K, Yang S, Xia S. Potential acute effects of suspended aluminum nitride (AIN) nanoparticles on soluble microbial products (SMP) of activated sludge. Journal of Environmental Sciences. 2017 Jul;57:284-92. https://doi.org/10.1016/j.jes.2017.02.001 
30. Zhang XQ, Yin LH, Tang M, Pu YP. ZnO, $\mathrm{TiO}(2), \mathrm{SiO}(2$,) and $\mathrm{Al}(2) \mathrm{O}(3)$ nanoparticles-induced toxic effects on human fetal lung fibroblasts. Biomed Environ Sci. 2011 Dec;24(6):661-9. https://doi.org/10.3967/0895-3988.2011.06.011

31. Berzina B, Trinkler L, Korsaks N, Ruska R, Krieke G, Sarakovskis A. F-center Luminescence and Oxygen Gas Sensing Properties of AlN Nanoparticles. Sensors \& Transducers. 2019 Nov;238(11):87-93. Available from: https://www.sensorsportal.com/HTML/DIGEST/november_2019/Vol_238/P 3145.pdf 